\title{
ВИКЛАДАННЯ ФАРМАКОЛОГІї - ДЕЯКІ ПІДСУМКИ І ПЕРСПЕКТИВИ
}

\author{
К. А. Посохова, О. М. Олещук, О. О. Шевчук \\ ДВНЗ “Тернопільський державний медичний університет імені І. Я. Горбачевського МОЗ Украӥни”
}

\section{PHARMACOLOGY TEACHING - SOME RESULTS AND PERSPECTIVES \\ K.A.Posokhova, O. M. Oleshchuk, O. O. Shevchuk \\ SHEI "Ternopil State Medical University by I. Ya. Horbachevsky of MPH of Ukraine”}

\begin{abstract}
Стаття присвячена деяким підсумкам викладання фармакології відповідно до змін в організації навчального процесу у Тернопільському державному медичному університеті, які відбулися за останні п'ять років, та перспективам подальшої діяльності.
\end{abstract}

The article is devoted to some results of pharmacology teaching accordingly the changes in educational process in Ternopil State Medical University which took place for the last five years and to future perspectives in this sphere.

Вступ. Україна чітко визначила орієнтири на входження до освітнього та наукового простору Свропи, здійснює модернізацію освітньої діяльності у контексті європейських вимог, щораз наполегливіше працює над практичними кроками впровадження принципів кредитно-модульної системи [3]. Швидкі темпи розвитку медичної науки у цілому та фармакології зокрема вимагають активного і цілеспрямованого впровадження світових стандартів у систему підготовки лікарів. Одним із плідних напрямків вирішення даного питання є здійснення перебудови навчального процесу, вдосконалення етапів та форм навчання $[2,7]$.

Фармацевтичний бум, який спостерігається 3 50-х років минулого століття, привів до зростання кількості лікарських засобів (Л3), які використовуються у світі для лікування та профілактики захворювань, до 350 тис. найменувань. Понад 14 тис. препаратів з цієї величезної кількості зареєстровано в Україні [1]. Серед усіх видів медичної допомоги медикаментозне лікування становить 80-85 \%. Подальший бурхливий розвиток фармації передбачає створення нових брендових та розширення номенклатури і ареолу застосування генеричних препаратів. 3 вищезазначеного витікає важливість не лише досконалого оволодіння студентами базовими фармакологічними знаннями, але й потреби у постійному їх оновленні, формування у них широкого фармакологічного світогляду. Це можна успішно досягнути, базуючись на багаторічному досвіді викладання предмета та використовуючи новітні технології організації навчального процесу: практично-орієнтованої системи навчання, методики “єдиного дня”, матрикулів практичних навичок, єдиного комплексного тестового іспиту тощо [4].

Основна частина. Незважаючи на те, що студенти початку нового тисячоліття є людьми, які широко використовують у своєму житті комп'ютерні технології, роль книги як джерела базових фармакологічних знань поки що не зменшилась. Наш досвід написання підручників 3 фармакології $[9,10,11,13$, $14,15]$ та тривалого викладання предмета свідчить, що на сьогодні недостатньо обмежуватись висвітленням властивостей Л3, навіть найсучасніших, 3 основним наголосом на молекулярних механізмах дії ліків. Глибоке знання останніх свідчить про фармакологічну ерудицію, сприяє виникненню ідей щодо створення нових препаратів, але, як правило, є недостатнім для того, хто повинен їх призначати хворій людині. Це міркування змусило нас перенести акценти на інші питання: короткий виклад вузлових моментів патогенезу патології, при якій призначається певна група Л3, зрідка - короткий екскурс в анатомію та фізіологію, прив'язування фармакодинаміки препарату, що описується, до конкретної клінічної патології, при якій його можна використовувати, деякі фармакотерапевтичні схеми найпоширеніших груп захворювань, обов'язково - можливі негативні наслідки застосування Л3 та заходи їх профілактики. При такому інтегрованому підході, який цілком відповідає практично-орієнтованій (Z-системі) навчання і передбачає тісний взаємозв' язок між фармакологією та іншими теоретичними та клінічними дисциплінами, фармакологічний матеріал оживає, стає більш

\footnotetext{
() К. А. Посохова, О. М. Олещук, О. О. Шевчук
} 
логічним, послідовним, що сприяє його запам'ятовуванню, а в майбутньому - осмисленому використанню у клініці. Крім того, вже під час вивчення фармакології на 3 курсі студент має глибоко усвідомити, що основними орієнтирами при пошуку найбільш ефективних схем лікування хворих людей повинна бути не гучна реклама ЛЗ, не традиції даного лікувально-профілактичного закладу, не мода на той чи інший лікарський препарат, а національні і світові рекомендації $з$ найвищим рівнем доказовості, підготовлені на основі аналізу багатоцентрових рандомізованих плацебо-контрольованих досліджень та випробувань 3 високим рівнем дизайну.

Впровадження системи "єдиного дня" у навчальний процес не змінило комплексу тієї фармакологічної інформації, якою студент має оволодіти під час навчання на 3 курсі, але сприяло більш чіткій іiї структуризації, глибшому зануренню у матеріал тем, які виносяться на заняття, підвищенню можливостей для опанування практичними навичками, опрацювання додаткових методичних джерел, більш демократичному i, водночас, більш раціональному і ефективному спілкуванню студентів з викладачами. Відповідно, перехід на нову систему організації навчального процесу вимагає серйозного методичного забезпечення всіх напрямків роботи студента. Тому впродовж останніх років діяльність викладачів кафедри спрямована на розробку не лише навчально-методичних матеріалів на паперових носіях, але насамперед стосується створення і вдосконалення презентацій лекцій, матеріалів для підготовки студентів до лекцій та практичних занять, методичних розробок до практичних занять, електронних варіантів таблиць, представлених на Веб-порталі університету. Для студентів-іноземців створено навчальний посібник 3 лікарської рецептури [17]. Студенти всіх факультетів можуть використовувати при виписуванні рецептів ще один навчальний посібник, створений співробітниками кафедри [16]. Електронні варіанти обох книг представлено на Веб-сторінці кафедри.

Особливістю фармакологічної науки, як вже зазначалось, є надзвичайна динамічність, що змушує постійно вдосконалювати всі методичні матеріали, які щорічно оновлюються.

В оптимізації та осучасненні навчального процесу велику роль відіграє використання відеосистем під час практичних занять та під час читання лекцій. Після оснащення двох навчальних кімнат відеосистемами 3 широкоформатними моніторами створено кафедральний банк відеофільмів (налічує понад 300 найменувань), який продовжує поповнюватись і вклю- чає відеофільми з усіх тем фармакології, які розбираються протягом навчального року та містять відомості про патогенез різних патологічних процесів, механізми дії ліків, їх властивості, зокрема побічні реакції, новинки фармакологічної науки. Кожна лекція з фармакології обов'язково ілюструється відеоматеріалами.

Для кращого опанування практичних навичок для студентів використовуються лінії практичних навичок - матрикули, які сприяють вдосконаленню вмінь виписування рецептів на різні лікарські форми, що передбачене вимогами освітньо-кваліфікаційної характеристики випускника. Протягом навчального року вдома і на практичних заняттях кожен студент 3 курсу виписує понад тисячу рецептів. Ще однією важливою практичною навичкою, якою оволодіває третьокурсник, $є$ вміння аналізувати та заповнювати форму про побічну реакцію (відсутність ефекту) ЛЗ при їх медичному застосуванні [6]. Студенти отримують базові знання про системи контролю ліків в Україні, про Державний експертний центр МОЗ України, систему фармакологічного нагляду, діяльність яких організовується відповідно до Закону України "Про лікарські засоби" та з урахуванням норм, що використовуються у міжнародній практиці. Формування у студентів усвідомлення необхідності, вміння і внутрішньої потреби постійного моніторингу та попередження побічних реакцій ЛЗ, які вони будуть реалізовувати у своїй лікарській діяльності, $€$ нагальною необхідністю сьогодення, важливою умовою ефективної та безпечної фармакотерапії. Такий підхід допомагає адаптувати студента до майбутніх життєвих ситуацій, в яких йому доведеться використовувати ліки в якості могутньої і, водночас, небезпечної зброї.

Сучасні форми навчання ставлять підвищені вимоги до викладацького складу. Відповідно, здійснено перехід на циклову систему навчання, що передбачає підвищення фахового рівня викладачів за напрямком вибраного циклу та удосконалення викладання дисципліни в цілому. При цьому в нас відсутні проблеми при роботі з англомовними студентами, оскільки 7 викладачів кафедри сертифіковані на право викладання англійською мовою (троє мають сертифікат найвищого рівня, четверо - 2 рівня).

Запорукою повноцінного опанування предметом $\epsilon$ регулярне й ефективне контролювання його засвоєння, чітке визначення критеріїв оцінювання проміжних та кінцевого рівнів знань, тим більше, коли йдеться про великі обсяги інформації. Цьому сприяють логічно побудовані методичні рекомендації для студентів, 
за допомогою яких контроль вивчення матеріалу на етапах самостійної роботи вдома та під час практичних занять здійснюється шляхом відповіді на питання, розв'язування тестових, фармакотерапевтичних і клініко-ситуаційних завдань, що сприяє формуванню в студентів абстрактно-пошукового, клініко-фармакологічного мислення.

Серед розроблених сучасною педагогічною наукою методів контролю чільне місце належить тестовому контролю, який забезпечує об'єктивність та зменшує суб' Єктивну компоненту системи оцінювання [5, 12]. Для нього характерні уніфікованість, одночасне охоплення контролем великої кількості студентів, можливість перевірки знань 3 усього масиву матеріалу, отримання систематичних “зрізів успішності” 3 одночасним зменшенням витрати часу як викладачів, так і студентів на здійснення контролю.

Широке використання у нашому університеті комп’ютерних технологій, крім удосконалення навчального процесу, забезпечує максимально об'єктивний контроль рівня знань студентів за системою “Moodle", у кафедральній базі якої налічується понад 10 тисяч тестових завдань трьома мовами, в тому числі рисунки та ситуаційні задачі, які регулярно поновлюються і коригуються. Викладачами кафедри постійно аналізується валідність тестових завдань та графіки результатів складання тестів. Студент має право 3'ясувати у викладача, який проводить заняття, допущені у роботі помилки, обговорити незрозумілі питання, опротестувати оцінку. Студенти, які не мали змогли написати тестовий контроль за програмою Moodle напередодні або не згідні з отриманою оцінкою, мають право виконати письмово контролюючу частину заняття, але вже у розширеному варіанті. Слід відмітити прогресуюче зростання кількості студентів, які беруть активну участь у щоденному тестовому контролі знань за системою Moodle. Серед україномовних студентів це практично 100 \%. 3 одного боку, прагнення до успішного складання електронних завдань заохочуєїх до повноцінної підготовки до заняття, з іншого - привчає працювати з електронними системами контролю знань і, відповідно, готує до семестрового комплексного тестового іспиту.

Семестрове комплексне тестування знань студентів, розпочате вперше в Україні у нашому університеті у 2006-2007 н. р., є об'єктивним, повністю незалежним від суб' єктивних факторів, критерієм оцінювання знань студентів відповідно до стандартів і рекомендацій Свропейської асоціації із забезпечення якості вищої освіти [8]. Практика показала, що успішно пройти цей рубіж можна, лише маючи грунтовні знання 3 предмета, оскільки величезна база тестових завдань з усіх дисциплін унеможливлює їх механічне запам' ятовування, а чітка організація підготовки і проведення іспитів Відділом незалежного тестування знань студентів та спеціально створеними 3 найбільш досвідчених викладачів комісіями практично виключає використання допоміжних несанкціонованих матеріалів під час іспиту. У переважаючій більшості випадків результати тестування студентів 3 фармакології відповідають середньому рівню їх поточної успішності, що свідчить, з одного боку, про належну якість їх підготовки, з іншого-про об' єктивність незалежного тестування знань.

Зважаючи на той факт, що основним критерієм ефективної викладацької роботи кожного колективу стають результати складання ліцензійних іспитів, для студентів всіх факультетів на кожному практичному занятті у контролюючу частину комплексних завдань обов'язково включені питання іспиту “Крок”, що є різними для всіх студентів. Крім того, відповідні питання обговорюються на семінарській частині заняття, що суттєво полегшує студентам сприйняття і запам'ятовування необхідного матеріалу. Відповідно на медичному факультеті результати складання ліцензійного іспиту “Крок” з фармакології з 2007 по 2011 р. коливаються від 76,7 до 86,5 \%, на стоматологічному - від 60,1 до 73,1 \% та на фармацевтичному факультеті - від 71,2 до 83,0 \%.

Об' єктивним критерієм якості підготовки студентів $\epsilon$ також результати другого туру предметної олімпіади. Протягом останніх п'яти років студенти 3 курсу медичного факультету ставали переможцями та призерами на всеукраїнських олімпіадах з фармакології, обіймаючи 1-ше, 2-ге та двічі - 3-тє місце. Переконливими є успіхи студентів 5 курсу фармацевтичного факультету, які на щорічних олімпіадах з фармації отримують за знання з фармакології перші місця.

Повноцінна підготовка кадрів майбутніх лікарів та провізорів передбачає виховання у них вміння логічно мислити, планувати свої дії, аналізувати отримані результати, тобто якостей, які завжди були характерними рисами науковця-дослідника. Відповідно, дуже важливо, щоб студент під час вивчення предмета на кафедрі перебував в атмосфері наукового пошуку, спілкувався з викладачами, для яких наукові дослідження є невід'ємною частиною їх фахового зростання, брав активну участь у науковій роботі, обирав свій шлях у науці.

На базі наукової лабораторії кафедри (Свідоцтво про атестацію на право проведення вимірювань у сфері розповсюдження державного метрологічного 
нагляду в галузі охорони здоров’я - № 000474 від 17.12.2007 р.), яка водночас є підрозділом Навчально-наукового інституту фармакології, гігієни та медичної біохіміі імені М. П. Скакуна, науковцями-фармакологами виконуються планові науково-дослідні роботи за такими напрямками: "Вплив попередників та інгібіторів синтезу оксиду азоту на перебіг метаболічних процесів при патологічних станах різного генезу” (2007-2009 рр.), “Пошук способів корекції уражень внутрішніх органів медикаментозного та іншого генезу” (2010-2012 рр.), “Встановлення біологічної активності (антигіпоксичної дії) у нових сполук - похідних теофіліну шляхом скринінгових досліджень" (2010-2012 рр.), остання - у рамках міжкафедральної НДР “Клініко-епідеміологічне та імунологічне обгрунтування вдосконалення профілактичних і лікувальних технологій при грипі та інших гострих респіраторних вірусних інфекціях". Крім того, за останні 5 років виконано 5 договірних наукових досліджень з сумарним бюджетом 410 тис. грн. У 20072011 рр. співробітниками кафедри офіційно захищено 6 кандидатських дисертацій, у 2011 р. відбулася апробація ще 3 кандидатських дисертацій, виконується 2 докторські 13 кандидатські дисертації. Крім цього, лабораторія кафедри надавала допомогу у проведенні досліджень для дисертантів ряду клінічних кафедр (2 докторські, 7 кандидатських дисертацій), магістерських робіт. У 2011 р. для наукової лабораторії кафедри придбано новий сучасний двопроменевий спектрофотометр Lambda 25 виробництва фірми Perkin Elmer, що дозволяє суттєво підвищити методичний рівень досліджень. За результатами виконаних наукових досліджень у 2009-2011 рр. отримано 5 патентів України на корисну модель. Викладачі кафедри активно співпрацюють 3 центральною науково-дослідною та міжкафедральною науковою клінічною лабораторіями, що діють у структурі медичного університету.

Заплановано розширення площ, зайнятих лабораторією, із розміщенням їі у цокольному приміщенні адміністративного корпусу університету та створенням всіх умов для проведення експериментальних досліджень відповідно до принципів GLP (Good Laboratory Practice - Належної лабораторної практики). Для вдосконалення рівня, розширення спектра наукових досліджень, забезпечення їх конкурентоспроможності лабораторію планується оснастити новими приладами.

За останні 5 років науковцями кафедри опубліковано 62 журнальні статті та понад 150 тез у матеріалах конгресів, з’іздів, конференцій. Співавторами таких публікацій неодноразово ставали студенти-гуртівці кафедри, учасники студентської наукової програми “Студент - майбутній фахівець високого рівня кваліфікації’. Результати наукових досліджень гуртківців щорічно доповідаються на всеукраїнських і міжнародних конференціях студентів та молодих вчених, кращі студентські наукові роботи відзначаються дипломами різних ступенів.

Тривалий досвід викладання предмета, постійний пошук новинок фармакологічної науки та прагнення до самовдосконалення, розширення наукового медичного світогляду дозволяє нам ділитися набутими знаннями не лише зі студентами та колегами-науковцями, але й з широким загалом. Результатом цього $\epsilon$ організація й проведення науково-практичних конференцій, за останні роки - 4 (“Безпечна фармакотерапія в Україні”, 29-30 жовтня 2008 р.; “Сучасний стан та перспективи розвитку доказової медицини у вітчизняній охороні здоров' я", 28-29 травня 2009 р., яка ввійшла у реєстр проведення всеукраїнських конференцій; “Безпечність ліків і фактори ризику небажаних ефектів фармакотерапіі”, 21-22 жовтня 2010 р.; "Біохімічні основи патогенезу ураження внутрішніх органів різної етіології та способи їх фармакологічної корекції, 3-4 листопада 2011 р.) та постійна публікація науково-популярних статей (за останні роки близько 20) у газетах “Ваше здоров'я”, “Медична академія", "Університетська лікарня", "RIA-плюс". Кафедра підтримує тісні зв’ язки з українськими та зарубіжними науковими й навчальними закладами, бере участь у міжнародних конференціях, семінарах.

Заплановане оснащення всіх навчальних кімнат кафедри відеосистемами $з$ широкоформатними моніторами дозволить ще активніше використовувати під час занять сучасні форми навчання 3 використанням електронних підручників, візуальних навчальних та інформаційно-довідникових систем, імітаційних моделей, баз тестів, бібліотечних фондів, наукових матеріалів 3 різних галузей світової медицини, які мають практично необмежені можливості, сприяють зростанню зацікавленості студентів у вивченні дисципліни, стирають бар'єри між навчальними закладами різних країн світу.

Висновки: 1. В умовах стрімкого науково-технічного прогресу та лавиноподібного наростання фахової інформації, для забезпечення максимальної адаптації викладачів та студентів до світового освітнього та медичного простору важливим $\epsilon$, поруч із збереженням цінного надбання минулого, об' єктивний аналіз та використання новітніх технологій у навчальному процесі та наукових дослідженнях. 
2. Впровадження новітніх технологій організації, контролю та оснащення навчального процесу (практично-орієнтованої системи навчання, методики “єдиного дня", системи “Moodle”, матрикулів практичних навичок, єдиного комплексного тестового іспиту, використання відеосистем, електронних баз методичних матеріалів тощо) сприяє досконалому оволодінню студентами базовими фармакологічними знаннями, формує у викладачів та студентів потребу у

\section{Література}

1. Довідник лікарських засобів. Випуск п'ятий / МОЗ України. Державний експертний центр. - Електронна версія. http://www.pharma-center.kiev.ua/view/dov lik zas).

2. Ковальчук Л. Я. Впровадження нових методик і систем навчального процесу в Тернопільському державному медичному університеті імені І. Я. Горбачевського / Л. Я. Ковальчук // Матеріали Всеукраїнської навчальнонаукової конференції “Проблеми інтеграції української медичної освіти у світовий освітній простір” (21-22.05.2009 p., м. Тернопіль). - С. 7-9.

3. Ковальчук Л. Я. Медична освіта в Україні та Болонський процес : реальність і шляхи переходу в Свропейський освітній простір / Ковальчук Л. Я., Мисула І. Р., Пашко К. О. // Матеріали науково-методичної конференції “Досвід впровадження основних засад Болонського процесу в систему вищої медичної (фармацевтичної) освіти" (14.04.2005 р., м. Тернопіль). - Тернопіль, 2005. - С. 24-31.

4. Ковальчук Л. Я. Новітні шляхи вдосконалення підготовки фахівців у Тернопільському державному медичному університеті імені І. Я. Горбачевського / Л. Я. Ковальчук // Матеріали Всеукраїнської навчально-наукової конференції з міжнародною участю “Впровадження кредитно-модульної системи організації навчального процесу у ВМ(Ф)НЗ України: результати, проблеми та перспективи" (21-22.05.2010р., м. Тернопіль). - Тернопіль, 2010. - C. 19-22.

5. Мілерян В. С. Методичні основи підготовки і проведення навчальних занять в медичних вузах (методичний посібник) / В. С. Мілерян. - К. : Хрещатик, 2004. - 80 с.

6. Про затвердження Порядку здійснення фармаконагляду за побічними реакціями лікарських засобів, дозволених для медичного застосування: наказ МО3 України № 898 від 27.12.2006 p. постійному їх оновленні та широкий фармакологічний світогляд.

3. Важливою компонентою діяльності викладацького колективу кафедри та повноцінної підготовки кадрів майбутніх лікарів та провізорів є високий рівень науково-дослідної роботи, яка виховує вміння логічно мислити, планувати свої дії, аналізувати отримані результати та є невід’ємною частиною фахового зростання.

7. Про затвердження плану заходів щодо розвитку вищої освіти на період до 2015 р.: Розпорядження Кабінету Міністрів України № 12728 від 27 серпня 2010p.

8. Сельський П. Р. ННВ незалежного тестування знань студентів / П. Р. Сельський // Медична академія. -2012. - № 2(307). - C. 3-4.

9. Скакун М. П. Основи фармакології з рецептурою / М. П. Скакун, К. А. Посохова. - Тернопіль : Укрмедкнига, 1999. $-547 \mathrm{c}$.

10. Скакун М. П. Основи фармакології з рецептурою : підручник / М. П. Скакун, К. А. Посохова. - [2-ге вид.]. Тернопіль : Укрмедкнига, 2004. -604 с.

11. Скакун М. П. Фармакологія : підручник/ М. П. Скакун, К. А. Посохова. - Тернопіль : Укрмедкнига, 2003. - 740 с.

12. Унгурян Л. М. Застосування тестової системи оцінки знань у навчальному процесі / Л. М. Унгурян, М. С. Образенко // Медична освіта. - 2011. - № 3. - С. 20-22.

13. Фармакологія. Підручник для студентів медичних факультетів / [І. С. Чекман, Н. О. Горчакова, Л. І. Козак та ін.]. - [2-ге вид.]. - Вінниця : Нова книга, 2011.- 784 с.

14. Фармакологія : підручник / [І. С. Чекман, Н. О. Горчакова, В. А. Туманов та ін.]; за ред. І. С. Чекмана. - К. : Вища шк., 2001.-598 c.

15. Фармакотерапія : підручник для студентів фармацевтичних факультетів / під ред. В. Крайдашенка, І. Г. Купновицької, І. М. Кліща, В. Г. Лизогуба. - Вінниця : Нова книга, 2010. $-644 \mathrm{c}$.

16. Pharmaceutical forms of drugs (Форми випуску лікарських засобів) / К. А. Posokhova, O. M. Oleshchuk, O. O. Shevchuk [et al.]. - Ternopil, 2011. -50 p.

17. Posokhova K.A. Rules of medical prescription writing/ K.A. Posokhova, O. M. Oleshchuk, O. O Shevchuk. - Ternopil, 2011.-42 p. 